\title{
Article \\ Food Waste Reduction from Customers' Plates: Applying the Norm Activation Model in South Korean Context
}

\author{
Wansoo Kim $^{1}{ }^{\circledR}$, Chen Che ${ }^{2}\left(\mathbb{D}\right.$ and Chul Jeong ${ }^{3, *}$ \\ 1 Department of Tourism Management, Gachon University, Seongnam 13120, Korea; warooo@gachon.ac.kr \\ 2 College of History and Tourism Culture, Inner Mongolia University, Hohhot 010021, China; \\ chechen@imu.edu.cn \\ 3 Division of Tourism Science, Hanyang University, Seoul 04763, Korea \\ * Correspondence: jeong72@hanyang.ac.kr
}

Citation: Kim, W.; Che, C.; Jeong, C. Food Waste Reduction from Customers' Plates: Applying the Norm Activation Model in South Korean Context. Land 2022, 11, 109. https://doi.org/10.3390/land 11010109

Academic Editors: Uttam Khanal and Sanzidur Rahman

Received: 18 December 2021

Accepted: 7 January 2022

Published: 10 January 2022

Publisher's Note: MDPI stays neutral with regard to jurisdictional claims in published maps and institutional affiliations.

Copyright: (C) 2022 by the authors. Licensee MDPI, Basel, Switzerland. This article is an open access article distributed under the terms and conditions of the Creative Commons Attribution (CC BY) license (https:// creativecommons.org/licenses/by/ $4.0 /)$.

\begin{abstract}
Researchers have pointed out the urgent need to tackle food waste from customers' plates, considering its environmental and socioeconomic impacts. Nonetheless, little is known about reducing food waste from customers' plates in the restaurant context. The present research successfully addressed how customers can reduce food waste by using the Norm Activation Model (NAM). A customer survey was employed to collect quantitative data to verify the hypotheses of this study. The NAM of this study involved awareness of environmental impact (of the restaurant industry), ascribed responsibility for food waste, and moral norm for food waste reduction as predictors for food waste reduction intention. In addition, this study adopted self-efficacy to food waste reduction as a moderator on the path from the moral norm for food waste reduction to food waste reduction intention. Our empirical results supported all the hypotheses suggested in the research model. Consequently, the findings of this study adequately explained how restaurant customers form their intention to reduce food waste and thus provided important clues about how it can be encouraged. For example, based on the findings, a nudging message may be displayed on the restaurant wall to raise customers' self-efficacy, saying, "Saving the earth is as easy as finishing your food or taking it home".
\end{abstract}

Keywords: food waste; norm activation model; self-efficacy; restaurant

\section{Introduction}

Food waste is increasingly drawing public attention, causing adverse environmental and socioeconomic impacts [1]. The foodservice industry discharges substantial food waste globally [2,3]. For example, the foodservice industry generates about $12 \%$ of the $28 \mathrm{EU}$ countries' total food waste [4]. US foodservice wastes up to $40 \%$ of the nation's total [5], implying considerable resource, energy, and environmental costs. The literature indicates that out-of-home dining results in more incredible food waste than home dining $[6,7]$. Nevertheless, foodservices have received much less scholarly attention than households in terms of food waste [6]. Further, foodservices have been studied much less than hotels regarding environmental impacts [2].

Although there is no official data available about amount of the food waste from the foodservices in South Korea, the food waste from households has been reported as decreasing every year [8] as households should pay costs in proportion to the amount of the food waste discharged. This policy is equally applied to the foodservices in South Korea. However, the cause of the problem lies in the fact that the foodservice operators directly pay the costs, not customers. Hence, customers are not directly rewarded by reducing their plate waste. It would be the fundamental reason people tend to be less motivated to reduce their food waste in restaurants than at home.

Undoubtedly, food waste is at the center of the harmful environmental influence of foodservices. Moreover, the food waste from foodservices is perfectly edible but discarded 
simply because it is no longer wanted [9]. This phenomenon is especially true for Korean food as typical Korean meals are served with several side dishes, which are a default option and thus easily left behind. Food waste causes climate change, land and water pollution, biodiversity loss, overharvesting, fossil fuel consumption, and many others [10]. The landfill is the most common method of food waste disposal in Korea, as most countries do [10]. In other words, food goes back to land, where it came from, as waste that pollutes the land, water, and air. Thus, there is need to intervene to reduce food waste, which is mostly 'edible,' in the foodservice sector [11]. Filimonau and De Coteau [12] asserts that continuous scholarly support is required to help foodservice managers in reveal the significance and determinants of effective mitigation of food waste.

In a broad sense, food waste is defined to include not only perfectly edible parts but also inedible parts (e.g., eggshells) and occasionally edible parts (e.g., potato skins, cucumber peels) [13]. However, given that the latter two food waste types are mostly unavoidable in the value-adding process in foodservices, this study pays particular attention to the perfectly edible food waste generated by restaurant customers. It is critical to address reducing edible food waste in the environmental perspective and the socioeconomic perspective [14], given that $11 \%$ of the world population are in hunger as of 2017 [15]. In this sense, restaurant customers' food waste reduction can be viewed from a moral viewpoint $[11,16]$. Accordingly, this study adopted the Norm Activation Model (NAM), which includes moral norm as a key driver of prosocial behavior [17], to predict restaurant customers' food waste reduction intention. The NAM is considered the most influential theory in the environmental literature [18].

This study is the first attempt to predict restaurant consumers' food waste reduction intention through their moral norm formation process. In addition, this study adopted self-efficacy to food waste reduction as a moderator on the path from the moral norm for food waste reduction to food waste reduction intention. Self-efficacy is a self-appraisal of one's capacity to organize and guide the actions essential to deal with certain situations [19]. Therefore, it follows that when customers believe they are capable of behaving in the ways required to mitigate food waste, their moral norm will drive them more strongly to form food waste reduction intention. By revealing the central roles of the moral norm and self-efficacy in forming customers' food waste reduction intention, this study contributes to drawing scholarly as well as managerial attention to how to simulate customers' moral norm and self-efficacy to food waste reduction, which is a win-win-win for the foodservices, customers, and the general public.

In sum, as the first study adopting the NAM in explaining restaurant customers' food waste reduction intention, this study aimed to verify (1) whether the NAM can successfully explain restaurant customers' food waste reduction intention, and (2) whether customers' self-efficacy to food waste reduction enhances the effect of their moral norm for food waste reduction on their food waste reduction intention in the South Korean restaurant context.

\section{Literature Review and Hypotheses}

\subsection{Food Waste}

The term "food waste" is interchangeably used with "food loss" by some scholars [20]. However, it is more practical to distinguish "food waste" from "food loss" as "food waste" represents the food lost at the consumption stage, whereas "food loss" represents the food lost at the value-adding stage [16,21]. Thus, food waste takes place at the household level as well as foodservice level. In the foodservice context, "food waste" refers to the food waste from customers' plates [22]. Given the growing dining-out trend, fueled by the advance of the foodservice industry and growth in income, increasing amount of edible food waste has been the focus of media, often blaming both foodservice businesses and their customers [12,21]. Witzel et al. [23] investigated Northern and Western European consumers, and applying cluster analysis led to the relationship between food-related lifestyle and food waste. Janssen et al. [24] examine the Dutch customer's household food management and food waste relation. Customers' overfull purchase behavior is the main 
reason for household food waste (Janssen et al.) [24]. Özbük [25] extension the theory of planned behavior by included price perception and food taste to discuss customers' food waste behavior in a restaurant. Goh and Je [26] applied theory planned behavior to explain the Generation $Z$ hotel employees' food wastage motivation. Their research also points out that using fresh food material to improve customer satisfaction renders hotel employees ascribed responsibility for food waste [26].

It implies that both foodservice operators and customers share responsibilities in reducing edible food waste. They can easily cooperate to reduce edible food waste from customers' plates since it is a relatively low-hanging fruit [27] compared to reducing food loss in the kitchen. Studies show that consumers are the biggest generator of food waste [28], and the wasted food can be avoided mainly by consumers' environmentconsiderate behaviors $[29,30]$. Certainly, foodservice operators can facilitate their customers environment-considerate behaviors [31]. Fortunately, restaurants are gradually paying attention to exemplary restaurant cases of food waste reduction [16].

\subsection{Norm Activation Model}

Developed by Schwartz [32], Norm Activation Model (NAM) has been extensively adopted to explain various prosocial behaviors [33,34], including energy saving behavior (e.g., Wittenberg, Blöbaum, and Matthies [35]), sustainable transport behavior (e.g., Bamberg, Hunecke, and Blöbaum [36]), environmental complaint behavior (e.g., Zhang, Liu, and Zhao [37]), and recycling behavior (e.g., Han and Hyun [38]). Prosocial behavior refers to the behavior intended to benefit other people or the general public [33]. In this regard, food waste reduction is undoubtedly a type of prosocial behavior [39]. Therefore, the NAM is the suitable theoretical model to explain food waste reduction behavior. However, no study has empirically verified restaurant customers' food waste reduction intention using the NAM.

The NAM consists of three antecedents that predict people's prosocial behavior. Namely, they are awareness of consequences (AC), ascribed responsibility (AR), and personal norm (PN) [32]. AC is defined as "whether someone is aware of the negative consequences for others or for other things one values when not acting pro-socially" [33] (p. 426). AR indicates "feelings of responsibility for the negative consequences of not acting pro-socially" [33] (p. 426). PN refers to a feeling of a "moral obligation to perform or refrain from specific actions" [33] (p. 426). The original norm activation model proposes that when people are aware of the negative consequences of not acting pro-socially (i.e., AC), they are likely to feel joint responsibility for the consequences of their non-prosocial behavior (i.e., AR). Thus, they would have a moral obligation to quit the non-prosocial behavior or adopt the alternative prosocial behavior (i.e., PN) [32]. Consequently, such felt moral norm would lead people to protect the environment $[32,33,40]$.

As mentioned, food waste reduction should be considered as a type of prosocial behavior. Therefore, following the NAM, the more people are aware of the negative consequences of the foodservice industry (i.e., $\mathrm{AC}$ ), the more they will feel responsible for the negative consequences of wasted foods (i.e., AR). In turn, the more people feel responsibility for the negative consequences of wasted foods (i.e., AR), the more they will feel a moral obligation to reduce food waste (i.e., PN). Finally, this felt moral obligation would induce people to form food waste reduction intention.

Whereas the original model suggests sequential influences (i.e., $\mathrm{AC} \rightarrow \mathrm{AR} \rightarrow \mathrm{PN}$ $\rightarrow$ prosocial behavior), some scholars have suggested both $\mathrm{AC}$ and $\mathrm{AR}$ as the predictors of PN [35] since AC initially triggers a person's moral obligation (i.e., PN) [41]. As such, previous studies have shown inconclusive viewpoints and each of the viewpoints has its own sound theoretical bases and empirical supports [35]. Therefore, the mediation model was adopted as the proposed model of this study to embrace both viewpoints. Using this well-proven theoretical model of the NAM, the following hypotheses were suggested in the context of customers' food waste in restaurants. 
Hypothesis 1 (H1). Awareness of environmental impact of the foodservice industry positively affects ascribed responsibility for food waste.

Hypothesis 2 (H2). Awareness of environmental impact of the foodservice industry positively affects moral norm for food waste reduction.

Hypothesis 3 (H3). Ascribed responsibility for food waste positively affects moral norm for food waste reduction.

Hypothesis 4 (H4). Moral norm for food waste reduction positively affects food waste reduction intention.

\subsection{Self-Efficacy to Food Waste Reduction}

Self-efficacy represents a personal belief in one's capability to act to tackle certain situations [19]. It leads people to exert greater efforts to engage in and maintain certain behaviors $[19,42]$. In other words, the more people believe they are capable of taking actions to achieve certain goals, the more they tend to take the actions. As such, selfefficacy motivates people to engage in specific behaviors. Therefore, with the same level of the moral norm for food waste reduction, those with higher self-efficacy to food waste reduction would form stronger food waste reduction intention than those who have lower self-efficacy. Thus, integrated into the NAM, this motivational effect of self-efficacy would work as a moderator as follows.

Hypothesis $\mathbf{5}$ (H5). Self-efficacy to food waste reduction will enhance the positive impact of moral norm for food waste reduction on food waste reduction intention.

Figure 1 graphically illustrates the study constructs and hypotheses suggested above.

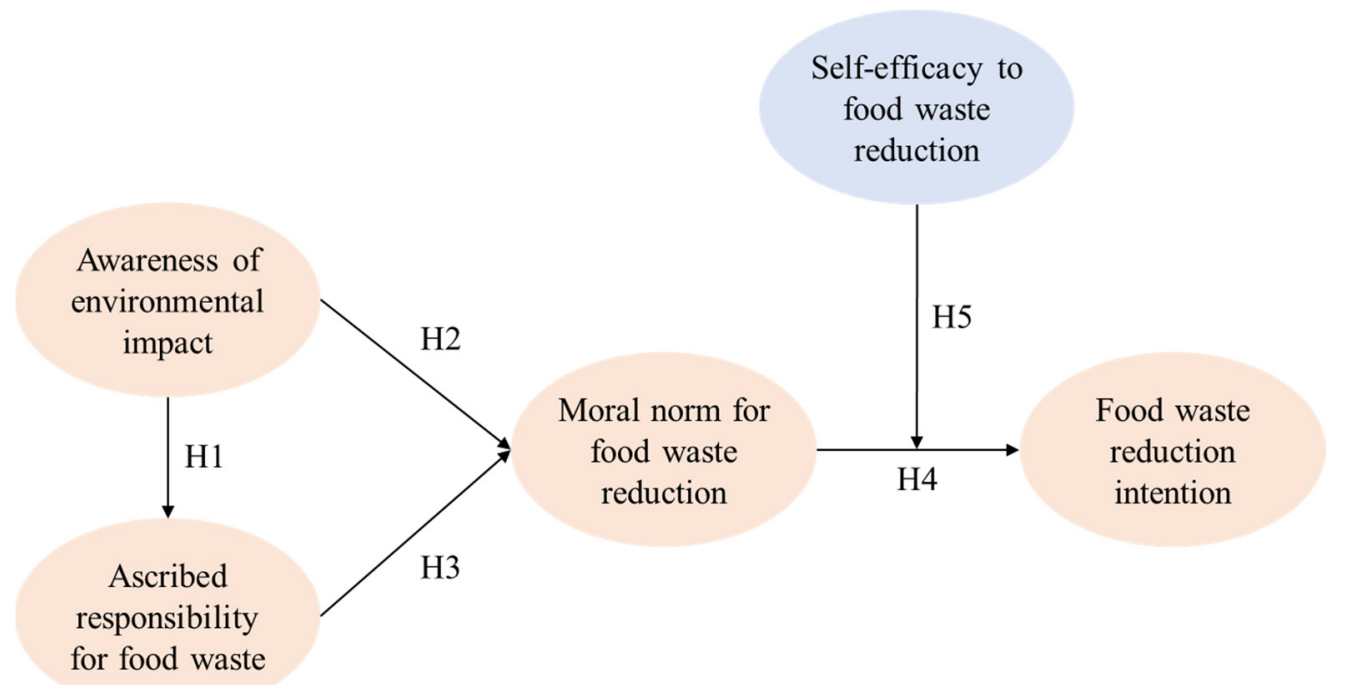

Figure 1. The proposed conceptual model.

\section{Method}

\subsection{Measures}

The measures of this study were borrowed from previous research in the environmental psychology and consumer behavior literature. All the constructs were measured with multiple items in a seven-point Likert scale ranging from "strongly disagree" (1) to "strongly agree" (7). Three items were used to measure awareness of environmental impact (e.g., "The restaurant industry causes pollution, climate change, and exhaustion of natural resources", "The restaurant industry may have a huge environmental impact on the at- 
mosphere, soil, and water", "The restaurant industry causes environmental deteriorations (e.g., excessive waste generation, waste of food materials)") [43]. Ascribed responsibility for food waste was evaluated with three items (e.g., "I feel jointly responsibility for reducing food waste while eating out at restaurants", "I feel jointly responsibility for the negative consequences of not practicing efforts to reduce food waste while eating out at a restaurant", "I feel jointly responsibility for the environmental pollution and ecological damage problems caused by not practicing efforts to reduce food waste while eating out at a restaurant") [44]. Four items were utilized to measure moral norm for food waste reduction (e.g., "It is contrary to my principles when I have to discard food", "I have been raised to eat all food I have taken myself", "Leaving leftovers give me a bad conscience", "It is contrary my principles when I have to discard food") [9]. Food waste reduction intention was evaluated with three items (e.g., "I try to eat all food that I have ordered", "The next time when I eat out at a restaurant, I intend to not throw food away", "The next time when I eat out at a restaurant, I will try to leave as little food as possible") [9]. Lastly, four items were adopted to assess self-efficacy to food waste reduction (e.g., "There are simple things I can do that reduce the negative consequences of food waste", "I can change my daily routines to prevent the problem caused by food waste", "My individual actions will contribute to a solution of the problem caused by food waste", "Changes in my daily routines will contribute to reducing the negative con-sequences of food waste") [45].

Along with these measures, the questionnaire included the research description and questions asking the respondent's demographic profiles. The face validity of the measures was tested by two foodservice academics and two industry professionals. Since all the measures adopted in this study had been well verified in various study contexts, no major modification was made. Just slight wording changes on the questions were made to make them clearer and easier to understand and finally the questionnaire was confirmed with a thorough review from the foodservice academic experts, who are professors in a hospitality program in a university in South Korea.

\subsection{Data Collection and Respondent Profiles}

The South Korean restaurant distinguished from other countries restaurant is the typical Korean meals offer the side dished, the most classic example is Hanjongshik. It means Korean consumers have potential food waste behavior. According to this situation, we decided to explore South Korean consumers. The data for this study were collected through the biggest online panel survey firm in South Korea. The firm's database has more than 1.4 million panel members, including all types of Koreans, from which the samples were randomly selected through the firm's random sampling algorithm. Then, the firm's system emailed an online invitation to the sampled panel members. Receiving the invitation, they accessed and filled out the online questionnaire. Only those who had dined out in a restaurant within the last three months were qualified to complete the survey. The description of the research was provided at the beginning of the questionnaire. Through this process, 315 usable responses were obtained. Because there were no incomplete or inconsistent responses, all the 315 data points remained for the analysis.

Of the 315 samples, $50.2 \%$ were female while $49.8 \%$ were male. The mean age was about 43.7 years old. $22.8 \%$ were in the $40^{\prime} \mathrm{s}, 20.0 \%$ were in the 30 s, $19.7 \%$ were in the $50^{\prime} \mathrm{s}$, $19.4 \%$ were in the $20^{\prime} \mathrm{s}$, and $18.1 \%$ were in $60^{\prime} \mathrm{s}$. Regarding education level, $65.7 \%$ reported a bachelor's degree, $13.7 \%$ reported graduate school or higher, $11.1 \%$ reported a high school diploma, and 9.5\% reported an associate degree. Lastly, in terms of monthly income, 36.8\% reported an income less than US\$2500, followed by $29.6 \%$ between US\$2501-4500, 17.4\% between US\$4501-6500, 8.9\% between US\$6501-8500, and 7.3\% over US\$8501. Overall, the samples appeared to well represent typical restaurant customers in South Korea. 


\section{Results}

\subsection{Measurement Model Evaluation}

A confirmatory factor analysis (CFA) was conducted to evaluate the fit of the measurement model to the data and verify the reliability, convergent validity, and discriminant validity of the measures [46]. As shown in Tables 1 and 2, the results of the CFA showed that the measurement model adequately fits the data $\left(\chi^{2}=259.534\right.$ ( $d f=108, p<0.001$, $\left.\left.\chi^{2} / d f=2.403\right), \mathrm{RMSEA}=0.067, \mathrm{CFI}=0.969, \mathrm{IFI}=0.969, \mathrm{TLI}=0.961\right)$. All the measures significantly loaded on their associated constructs at $p<0.001$. The composite reliability values of the constructs were all above the recommended cutoff of 0.700 , ranging from 0.842 to 0.952 , showing satisfactory internal consistency of the measures for each construct [47]. The average variance extracted (AVE) values of the constructs all exceeded the suggested cutoff of 0.500 [47], ranging from 0.574 to 869 . It indicated that the measures of each construct had adequate convergent validity [48]. Lastly, satisfactory discriminant validities of the constructs were established since the AVE value of each construct was above the squared correlations with the other constructs [48].

Table 1. Measurement model assessment.

\begin{tabular}{|c|c|}
\hline Constructs and Measures & Loading \\
\hline \\
\hline $\begin{array}{c}\text { The restaurant industry causes pollution, climate change, and exhaustion of natural } \\
\text { resources. }\end{array}$ & 0.882 \\
\hline $\begin{array}{c}\text { The restaurant industry may have a huge environmental impact on the atmosphere, } \\
\text { soil, and water. }\end{array}$ & 0.904 \\
\hline $\begin{array}{l}\text { The restaurant industry causes environmental deteriorations (e.g., excessive waste } \\
\text { generation, waste of food materials). }\end{array}$ & 0.897 \\
\hline \multicolumn{2}{|l|}{ Ascribed responsibility for food waste $(C R=0.952, A V E=0.869)$} \\
\hline I feel jointly responsibility for food waste reduction while eating out at a restaurant. & 0.904 \\
\hline $\begin{array}{l}\text { I feel jointly responsibility for the negative consequences of not practicing efforts to } \\
\text { reduce food waste while eating out at a restaurant. }\end{array}$ & 0.954 \\
\hline $\begin{array}{l}\text { I feel jointly responsibility for the environmental pollution and ecological damage } \\
\text { problems caused by not practicing efforts to reduce food waste while eating out at a } \\
\text { restaurant. }\end{array}$ & 0.938 \\
\hline \multicolumn{2}{|l|}{ Moral norm for food waste reductio $(C R=0.842, A V E=0.574)$} \\
\hline I feel guilty about poor people when I leave leftover food. & 0.612 \\
\hline Leaving leftovers give me a bad conscience. & 0.762 \\
\hline I have been raised to eat all food I have taken myself. & 0.789 \\
\hline It is contrary my principles when I have to discard food. & 0.847 \\
\hline \multicolumn{2}{|l|}{ Food waste reduction intention $(C R=0.934, A V E=0.826)$} \\
\hline The next time when I eat out at a restaurant, I will try to eat all food that I order. & 0.930 \\
\hline The next time when I eat out at a restaurant, I intend to not throw food away. & 0.917 \\
\hline $\begin{array}{l}\text { The next time when I eat out at a restaurant, I will try to leave as little food as } \\
\text { possible. }\end{array}$ & 0.878 \\
\hline \multicolumn{2}{|l|}{ Self-efficacy to food waste reduction $(C R=0.933, A V E=0.777)$} \\
\hline There are simple things I can do to reduce the negative consequences of food waste. & 0.823 \\
\hline I can change my daily routines to prevent the problem caused by food waste. & 0.861 \\
\hline $\begin{array}{l}\text { My individual actions will contribute to a solution of the problem caused by food } \\
\text { waste. }\end{array}$ & 0.926 \\
\hline $\begin{array}{l}\text { Changes in my daily routines will contribute to reducing the negative consequences } \\
\text { of food waste. }\end{array}$ & 0.912 \\
\hline
\end{tabular}


Table 2. Results of the confirmatory factor analysis and correlations $(n=315)$.

\begin{tabular}{|c|c|c|c|c|c|c|c|}
\hline Construct & (a) & (b) & (c) & (d) & (e) & CR & AVE \\
\hline (a) Awareness of environmental impact & - & $0.101^{b}$ & 0.073 & 0.008 & 0.048 & 0.923 & 0.800 \\
\hline (b) Ascribed responsibility for food waste & $0.318^{\mathrm{a}}$ & - & 0.430 & 0.358 & 0.437 & 0.952 & 0.869 \\
\hline (c) Moral norm for food waste reduction & 0.270 & 0.656 & - & 0.493 & 0.316 & 0.842 & 0.574 \\
\hline (d) Food waste reduction intention & 0.092 & 0.598 & 0.702 & - & 0.494 & 0.934 & 0.826 \\
\hline (e) Self-efficacy to mitigate climate crisis & 0.219 & 0.661 & 0.562 & 0.703 & - & 0.933 & 0.777 \\
\hline Mean & 4.43 & 5.30 & 4.83 & 5.75 & 5.62 & & \\
\hline$S D$ & 1.24 & 1.19 & 1.20 & 1.10 & 0.94 & & \\
\hline \multicolumn{4}{|c|}{$\begin{array}{l}\text { Goodness-of-fit statistics: } \\
\chi^{2}=259.534\left(d f=108, p<0.001, \chi^{2} / d f=2.403\right) \\
\text { RMSEA }=0.067, \mathrm{CFI}=0.969, \mathrm{IFI}=0.969, \mathrm{TLI}=0.961\end{array}$} & \multicolumn{4}{|c|}{$\begin{array}{l}\text { a Correlation } \\
\text { b Squared correlation }\end{array}$} \\
\hline
\end{tabular}

Note: $\mathrm{CR}=$ composite reliability; $\mathrm{AVE}=$ average variance extracted; $\mathrm{SD}=$ standard deviation; RMSEA = root mean square error of approximation; $\mathrm{CFI}=$ comparative fit index; IFI = incremental fit index; TLI = Tucker-Lewis index.

\subsection{Structural Model Analysis and Hypotheses Testing}

A structural equation modeling (SEM) was conducted to test the hypothesized relationships in the structural model. The model was shown to fit the data well $\left(\chi^{2}=151.903\right.$ $\left(d f=60, p<0.001, \chi^{2} / d f=2.532\right)$, RMSEA $\left.=0.070, \mathrm{CFI}=0.974, \mathrm{IFI}=0.974, \mathrm{TLI}=0.966\right)$. As shown in Table 3 and Figure 2, the suggested causal relationships satisfactorily accounted for the variance in food waste reduction intention $\left(R^{2}=0.542\right) .47 .6 \%$ of the total variance in moral norm for food waste reduction and $10.1 \%$ of the total variance in ascribed responsibility for food waste were accounted for by its antecedent(s).

Table 3. Results of the structural equation modeling $(n=315)$.

\begin{tabular}{lllcr}
\hline & Independent Construct & Dependent Construct & Coefficient & $t$-Value \\
\hline H1 & Awareness of environmental impact & Ascribed responsibility for food waste & 0.318 & $5.425 * * *$ \\
H2 & Awareness of environmental impact & Moral norm for food waste reduction & 0.032 & 0.607 \\
H3 & Ascribed responsibility for food waste & Moral norm for food waste reduction & 0.679 & $8.833^{* * *}$ \\
H4 & Moral norm for food waste reduction & Food waste reduction intention & 0.736 & $9.101 * * *$ \\
\hline & & Goodness-of-fit statistics: \\
Total variance explained $\left(R^{2}\right):$ & $\chi^{2}=151.903(d f=60, p<0.001$, \\
$R^{2}$ for ascribed responsibility for food waste $=0.101$ & $\left.\chi^{2} / d f=2.532\right)$, RMSEA $=0.070$, \\
$R^{2}$ for moral norm for food waste reduction $=0.476$ & CFI =0.974, IFI =0.974, \\
$R^{2}$ for food waste reduction intention $=0.542$ & & TLI $=0.966$
\end{tabular}

Note: RMSEA = root mean square error of approximation; $\mathrm{CFI}=$ comparative fit index; $\mathrm{IFI}=$ incremental fit index TLI $=$ Tucker-Lewis index.

The SEM results showed that awareness of environmental impact significantly and positively affected ascribed responsibility for food waste $(\beta=0.318, p<0.001)$, supporting H1. However, awareness of environmental impact did not significantly affect moral norm for food waste reduction $(\mathrm{H} 2)(\beta=0.032, p>0.05)$. An additional mediation test revealed that this insignificant effect was resulted from a full mediation by ascribed responsibility for food waste. Specifically, when the path from ascribed responsibility for food waste to moral norm for food waste reduction was constrained to zero, the effect of awareness of environmental impact on moral norm for food waste reduction became significant $(\beta=0.267, t=4.05$ $(p<0.001))$. The $\chi^{2}$ difference between the original model and the constrained model $\left(\Delta \chi^{2}(1)=135.681\right)$ was significant at $p<0.001$, indicating that the mediation effect was highly significant. Going back to the original model, ascribed responsibility for food waste significantly and positively affected moral norm for food waste reduction $(\beta=0.679$, $p<0.001)$ and, in turn, moral norm for food waste reduction significantly and positively affected food waste reduction intention $(\beta=0.736, p<0.001)$, supporting $\mathrm{H} 3$ and $\mathrm{H} 4$. 


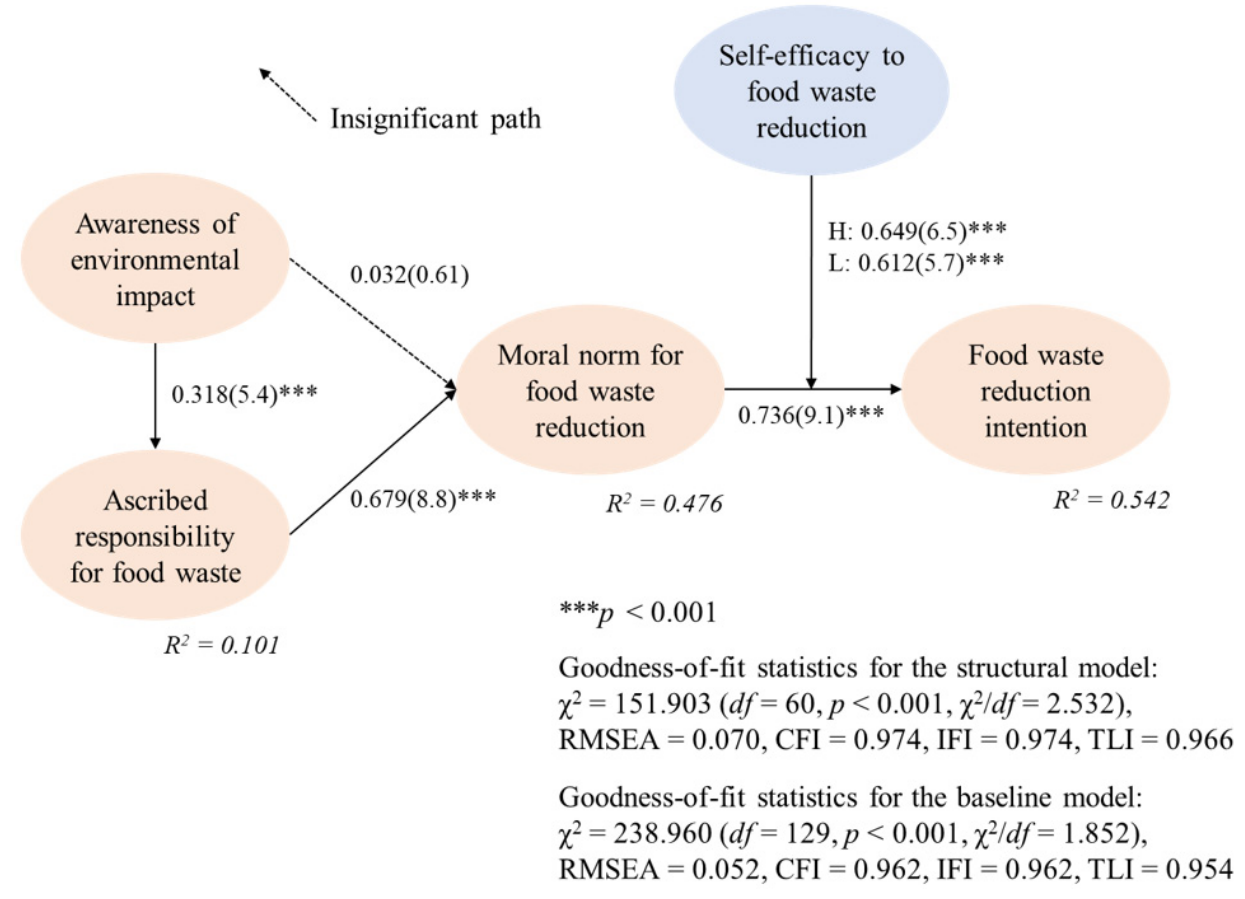

Figure 2. The structural model results.

Next, the indirect effects of the mediating constructs were tested. As in Table 4, awareness of environmental impact $(\beta=0.183, p<0.05)$ and ascribed responsibility for food waste $(\beta=0.500, p<0.01)$ showed a significant positive indirect impact on food waste reduction intention. In addition, awareness of environmental impact showed a significant positive indirect impact $(\beta=0.216, p<0.05)$ on moral norm for food waste reduction. Lastly, in terms of the total effect, the findings showed that moral norm for food waste reduction exerted the greatest effect on food waste reduction intention $(\beta=0.736, p<0.01)$, followed by ascribed responsibility for food waste $(\beta=0.500, p<0.01)$, and awareness of environmental impact $(\beta=0.183, p<0.05)$.

Table 4. Results of the indirect and total effect assessment.

\begin{tabular}{lcc}
\hline \multicolumn{1}{c}{ On } & Indirect Effect of \\
\hline & Awareness of Environmental Impact & $\begin{array}{c}\text { Ascribed Responsibility } \\
\text { for Food Waste }\end{array}$ \\
\hline Moral norm for food waste reduction & $0.216^{*}$ & - \\
Food waste reduction intention & $0.183^{*}$ & $0.500 *$ \\
\hline Total effect on food waste reduction intention: & & $* p<0.05,{ }^{* *} p<0.01$ \\
$\beta$ awareness of environmental impact $=0.183^{*}$ & & \\
$\beta$ ascribed responsibility for food waste $=0.500^{* *}$ & \\
$\beta$ moral norm for food waste reduction $=0.736^{* *}$ & & \\
\hline
\end{tabular}

\subsection{Invariance Model Test}

A metric invariance test was conducted to evaluate the hypothesized moderating effect of self-efficacy to food waste reduction. The respondents were separated into high and low self-efficacy to food waste reduction groups through a K-means cluster analysis. 187 respondents were clustered into the high group and 128 into the low group. In turn, a baseline model involving both the high and low groups were created. Our results showed that the baseline model satisfactorily fit the data $\left(\chi^{2}=238.960(d f=129, p<0.001\right.$, $\left.\chi^{2} / d f=1.852\right)$, RMSEA $=0.052$, CFI $=0.962$, IFI $=0.962$, TLI $\left.=0.954\right)$. Table 5 and Figure 2 show the detailed results of the baseline model test. Subsequently, the baseline model 
was compared with the nested model where the path from moral norm for food waste reduction to food waste reduction intention was constrained to be equivalent. As expected, our results showed that the influence of moral norm for food waste reduction on food waste reduction intention differed significantly between the high and low self-efficacy groups $\left(\Delta \chi^{2}(1)=4.70, p<0.05\right)$, supporting H5. The $\chi^{2}$ difference test was shown in Table 5 .

Table 5. Results of the invariance model assessment.

\begin{tabular}{|c|c|c|c|c|c|c|}
\hline \multirow{2}{*}{ Linkage } & \multicolumn{2}{|c|}{$\begin{array}{c}\text { High SMCC Group } \\
\qquad(n=187)\end{array}$} & \multicolumn{2}{|c|}{$\begin{array}{l}\text { Low SMCC Group } \\
\qquad(n=128)\end{array}$} & \multirow{2}{*}{$\begin{array}{l}\text { Baseline Model } \\
\text { (Freely Estimated) }\end{array}$} & \multirow{2}{*}{$\begin{array}{l}\text { Nested Model } \\
\text { (Equally Constrained) }\end{array}$} \\
\hline & $\beta$ & $t$-Value & $\beta$ & $t$-Value & & \\
\hline $\begin{array}{l}\text { Moral norm for food } \\
\text { waste reduction } \\
\rightarrow \text { Food waste } \\
\text { reduction intention }\end{array}$ & 0.649 & $6.448^{* * *}$ & 0.612 & $5.719^{* * *}$ & $\chi^{2}(129)=238.960$ & $\chi^{2}(130)=243.658^{a}$ \\
\hline \multicolumn{3}{|c|}{$\begin{array}{l}\text { Chi-square difference test: } \\
{ }^{a} \Delta \chi^{2}(1)=4.70, p<0.05 \text { (H5: Supported) } \\
* * *<<0.001\end{array}$} & \multicolumn{4}{|c|}{$\begin{array}{l}\text { Goodness-of-fit statistics for the baseline model: } \\
\chi^{2}=238.960\left(d f=129, p<0.001, \chi^{2} / d f=1.852\right) \\
\text { RMSEA }=0.052, \text { CFI }=0.962, \text { IFI }=0.962, \text { TLI }=0.954\end{array}$} \\
\hline
\end{tabular}

Note: SMCC = self-efficacy to mitigate climate crisis.

\section{Discussions}

\subsection{Discussions and Implications}

The current research tested the relationship of awareness of environmental impact. Ascribed responsibility of food waste, moral norm for food waste reduction, self-efficacy to food waste reduction, and food waste reduction intention, modeled restaurant consumers' food waste reduction intention through the moral norm formation process. The hypothesis also explored the mediate and moderate effect and robust evidence of the relationship between self-efficacy to food waste reduction and its direct determinants. The norm activation model in this research act as a firm theoretical framework that illuminates the restaurant consumer's moral obligation and food waste reduction intention. The Seoul metropolitan government implement the "Pay as You Throw" system to encourage its people to reduce food waste [49]. Moreover, as mentioned in the literature review, the restaurant should make the customer aware that wasting food is not a good habit. It also has irreversible environmental consequences [40].

The three antecedents of the norm activation model (awareness of the environmental impact, ascribed responsibility for food waste, the moral norm for food waste reduction) were adopted to explain the energy-saving behavior $[35,37,38]$. The goal of the restaurant is to avoid food wastage [16,31]. The findings of this study revealed that ascribed responsibility for food waste fully mediated the relationship between awareness of environmental impact (of the foodservice industry) and moral norm for food waste reduction. This result is in line with previous studies that took such sequential relationships in green research (e.g., Meng, Chua, Ryu, and Han [50]; Steg and De Groot [41]). As mentioned in the literature review and hypotheses section, this study adopted the mediation version of the NAM, where both AC and AR affect PN [35], to embrace both rivaling versions of the NAM. The findings of this study indicate that the sequential version of the NAM is more appropriate in the context of this study. It means that when customers are aware of the environmental damage caused by the foodservice industry, they are more likely to feel joint responsibility for the negative consequences of their food waste. This feeling leads them to feel moral norm to reduce their food waste. Therefore, arousing people's attention to potential environmental impacts of foodservices is certainly the first step to reduce customers' food waste. Then, people will feel responsibility for their plate waste and, in turn, form moral norm to decrease it. As shown in Figure 2, the awareness of environmental impact is not significant to the moral norm for food waste reduction. This result differs from some prior studies $[35,41]$. This result may be explained by customers' lack of 
knowledge about restaurant food waste. Xu et al. [51] analyzed the Chinese restaurant and detected the consumer's food taste and the big meal directly influences customer's dishes waste. Combined with this research finding, the restaurants need to know food tastes yucky and more significant portions are not pro-environment behavior. The most critical point is consumers didn't become aware that they didn't eat the not tasty food or order overfilled dishes is environmentally unfriendly behavior. As a South Korean situation, the restaurant inquiry about the consumers' need to freebie or not. According to the analysis results, customers' self-efficacy to food waste reduction enhanced the effect of moral norm for food waste reduction on food waste reduction intention. It indicates that with the same level of moral norm, the customers who recognize there are simple things they can do to reduce their plate waste would develop stronger intention to reduce plate waste than those who do not. This finding indicates that foodservice managers should make it easy and convenient for customers, for example, to order just as much food as they can finish and choose the right menu that suits their taste. Managers can even make customers feel proud of taking leftover food home, for example, by putting a message saying "I am proudly saving the earth" on a takeout bag. The restaurant can make rules like "Pay as You Throw" [49]. Moreover, perhaps restaurants offer reduced-sized plates, or encouraging eco-friendly "take-home" containers can solution the leftovers problem. On the other side, government policymaking plays a key background role in food waste.

Filimonau et al. [52] pointed out that it is challenging for foodservice managers to identify food waste and measure its exact amount. However, our society would not expect managers to reduce food waste by $100 \%$. We just hope they do their best in reducing food waste together with their customers. Whatever the result would be, the general public would appreciate their efforts and sincerity since people would believe the joint effort by managers and customers will eventually produce meaningful results in our society. The ultimate outcome to the restaurant would be their improved image as a restaurant of "good influence" besides better financial outcomes through saved costs and improved operational efficiency, coming from increased customer traffic owing to improved reputation. Customers are smarter and increasingly environment-sensitive than ever before.

Research suggests customers' food waste reduction intention would not be enough to predict their actual actions. For example, Dolnicar, Juvan, and Grün [53] suggested some interventions can promote customers' actual food waste reduction behavior such as using a stamp collection booklet for zero plate waste or a flyer asking customers to help in reducing food waste in hotel buffets. Elhoushy [54] highlighted the importance of having motivational balance for an intention to lead to an action. In other words, in a case where a customer has conflicting motivations to avoid carrying doggy bags as well as to leave zero plate waste, the probability for the customer to take leftover home would be less than in a case where the customer has compatible motivations. To induce customers' intention to actual action, managers should be able to remove customers' conflicting motivations by changing their perceptions on food waste reduction practices such as carrying takeout bags, asking to take back unwanted side dishes, ordering just enough food to eat, and so on. Those are great practices to be proud of, not to be shame of. It is scientifically and ethically correct. Therefore, it is what socially responsible foodservices should do in this era of climate crisis.

Further, foodservices may consider providing customers with an option to choose their portion size as pizzerias do. This practice can help customers to order right amount of food for them to finish. This practice will not necessarily reduce foodservices' revenue since a half portion size does not mean a half price. Involving some fixed costs, a half-size menu is reasonable to be priced, for example, around $75 \%$ of the price of a whole-size menu. This practice would be especially welcomed by female one-person household customers, who are steadily increasing in number globally. They are sensitive not only about healthy diet but also about environment-friendliness and, critically, they are active in online communication [55]. 


\subsection{Limitations and Future Research}

This study includes the following limitations. First, the present study used the responses from South Korean customer samples. This may lead to a concern about the generalizability of the results. Future research may extend this study by test a similar conceptual model in other countries as food waste is a global matter. Second, like other socio-psychological studies dealing with people's decision-making processes (e.g., Ajzen [56]; Perugini and Bagozzi [57]), this study investigated customers' general decision formation. Future research may measure customers' actual food waste reduction behaviors to assess their behavioral changes. Third, in this study, the impact of restaurant types (e.g., fine dining, casual dining, fast casual) was not considered. It increases the generalizability of the results. Fourth, the current research uses the questionnaire to discuss consumers' potential behavior. Fifth, future studies can research the relationship between government policy and norm activation model theory. However, future research may focus on some specific types of foodservices when interested in finding type-specific results.

\section{Conclusions}

When tested in the context of food waste from restaurant customers' plates, the norm activation model revealed moral norm for food waste reduction as the most influential antecedent of customers' food waste reduction intention $\left(R^{2}=54.2 \%\right.$, see Table 3$)$. It implies that when customers feel guilty or uncomfortable about leaving food behind, they are more likely to intend to finish all the food on their plates or take it home. The previous research shows that the preventive measures of food waste is stakeholders (e.g., government, local enterprise, restaurant industry and so no) make a comprehensive action plan to promote restaurant pro-environment programs [58]. Especially, there is some change of food waste since COVID-19 pandemic [59-63]. Given that making customers happy is a basic role of foodservice managers, they should make customers feel comfortable by helping them not to leave food behind. Managers can help customers to order just as much as they can finish or to take leftover food home easily and comfortably, or rather proudly. It is apparent that if managers can do so, the amount of food waste from customers' plates will be decreased dramatically. At first glance, managers may think sales volume would decrease. However, in the long run, such socially responsible practices will certainly pay back to them since customers these days are increasingly becoming sensitive about climate change and socially responsible management of all types of businesses $[64,65]$. Further, consumers are today widely connected to so many people online to spread good word of mouth so easily and quickly than ever before.

Author Contributions: Conceptualization, W.K.; methodology, W.K.; writing—original draft preparation, W.K.; writing —review and editing, C.C.; visualization, C.C.; supervision, C.J.; project administration, C.J.; funding acquisition, C.J. All authors have read and agreed to the published version of the manuscript.

Funding: This research received no external funding.

Institutional Review Board Statement: Because of the observational nature of the study, and in the absence of any involvement of therapeutic medication, no formal approval of the Institutional Review Board of the local Ethics Committee was required. Nonetheless, all subjects were informed about the study and participation was fully on a voluntary basis. Participants were ensured of confidentiality and anonymity of the information associated with the surveys. The study was conducted in accordance with the Helsinki Declaration.

Informed Consent Statement: Not applicable.

Data Availability Statement: The dataset used in this research are available upon request from the corresponding author. The data are not publicly available due to restrictions i.e., privacy or ethical.

Conflicts of Interest: The authors declare no conflict of interest. 


\section{References}

1. Cosgrove, K.; Vizcaino, M.; Wharton, C. COVID-19-related changes in perceived household food waste in the united states: A cross-sectional descriptive study. Int. J. Environ. Res. Public Health 2021, 18, 1104. [CrossRef]

2. Filimonau, V.; Sulyok, J. ‘Bin it and forget it!': The challenges of food waste management in restaurants of a mid-sized Hungarian city. Tour. Manag. Perspect. 2021, 37, 100759. [CrossRef]

3. Huang, C.H.; Liu, S.M.; Hsu, N.Y. Understanding global food surplus and food waste to tackle economic and environmental sustainability. Sustainability 2020, 12, 2892. [CrossRef]

4. Stenmarck, Â.; Jensen, C.; Quested, T.; Moates, G.; Buksti, M.; Cseh, B.; Juul, S.; Parry, P.; Politano, A.; Redlingshofer, B.; et al. Estimates of European Food Waste Levels; IVL Swedish Environmental Research Institute: Stockholm, Sweden, 2016.

5. ReFED. The Foodservice Food Waste Action Guide. 2018. Available online: https://www.refed.com/downloads/Foodservice_ Guide_Web.pdf. (accessed on 20 July 2021).

6. Wang, L.E.; Liu, G.; Liu, X.; Liu, Y.; Gao, J.; Zhou, B.; Gao, S.; Cheng, S. The weight of unfinished plate: A survey based characterization of restaurant food waste in Chinese cities. Waste Manag. 2017, 66, 3-12. [CrossRef] [PubMed]

7. Youngs, A.J.; Nobis, G.; Town, P. Food waste from hotels and restaurants in the UK. Waste Manag. Res. 1983, 1, $295-308$.

8. Ministry of Environment. Available online: https://eng.me.go.kr/eng/web/index.do?menuId=466\&firstItemIndex=Topics (accessed on 3 November 2021).

9. Visschers, V.H.; Wickli, N.; Siegrist, M. Sorting out food waste behaviour: A survey on the motivators and barriers of self-reported amounts of food waste in households. J. Environ. Psychol. 2016, 45, 66-78. [CrossRef]

10. FAO. Food Wastage Footprint: Impacts on Natural Resources; The Food and Agriculture Organization: Rome, Italy, 2013.

11. Filimonau, V.; Nghiem, V.N.; Wang, L.E. Food waste management in ethnic food restaurants. Int. J. Hosp. Manag. 2021, 92, 102731. [CrossRef]

12. Filimonau, V.; De Coteau, D.A. Food waste management in hospitality operations: A critical review. Tour. Manag. 2019, 71, 234-245. [CrossRef]

13. Papargyropoulou, E.; Lozano, R.; Steinberger, J.K.; Wright, N.; bin Ujang, Z. The food waste hierarchy as a framework for the management of food surplus and food waste. J. Clean. Prod. 2014, 76, 106-115. [CrossRef]

14. Attiq, S.; Chau, K.Y.; Bashir, S.; Habib, M.D.; Azam, R.I.; Wong, W.K. Sustainability of Household Food Waste Reduction: A Fresh Insight on Youth's Emotional and Cognitive Behaviors. Int. J. Environ. Res. Public Health 2021, 18, 7013. [CrossRef]

15. WFP-World Food Programme. Global Hunger Continues to Rise, New UN Report Says. 2018. Available online: https: / / www.wfp.org/news/global-hunger-continues-rise-new-un-report-says\#: \{\}:text=Global\%20hunger\%20continues\%20to\% 20rise $\% 2 \mathrm{C} \% 20$ new $\% 20$ UN $\% 20$ report,children $\% 20$ stunted $\% 2 \mathrm{C} \% 20$ putting $\% 20$ hunger $\% 20$ eradication $\% 20$ goal $\% 20$ at $\% 20$ risk. (accessed on 20 July 2021).

16. Martin-Rios, C.; Demen-Meier, C.; Gössling, S.; Cornuz, C. Food waste management innovations in the foodservice industry. Waste Manag. 2018, 79, 196-206. [CrossRef] [PubMed]

17. Han, H.; Chi, X.; Kim, C.; Ryu, H. Activators of airline customers' sense of moral obligation to engage in pro-social behaviors: Impact of CSR in the Korean marketplace. Sustainability 2020, 12, 4334. [CrossRef]

18. Han, H.; Hwang, J.; Lee, M.J.; Kim, J. Word-of-mouth, buying, and sacrifice intentions for eco-cruises: Exploring the function of norm activation and value-attitude-behavior. Tour. Manag. 2019, 70, 430-443. [CrossRef]

19. Bandura, A. Environmental Sustainabiltiy by Sociocognitive Deceleration of Population Growth. In Psychology of Sustainable Development; Springer: Boston, MA, USA, 2020; pp. 209-238.

20. Gorzeń-Mitka, I.; Bilska, B.; Tomaszewska, M.; Kołożyn-Krajewska, D. Mapping the structure of food waste management research: A co-keyword analysis. Int. J. Environ. Res. Public Health 2020, 17, 4798. [CrossRef]

21. Dhir, A.; Talwar, S.; Kaur, P.; Malibari, A. Food waste in hospitality and food services: A systematic literature review and framework development approach. J. Clean. Prod. 2020, 270, 122861. [CrossRef]

22. Parfitt, J.; Barthel, M.; Macnaughton, S. Food waste within food supply chains: Quantification and potential for change to 2050. Philos. Trans. R. Soc. B Biol. Sci. 2010, 365, 3065-3081. [CrossRef]

23. Aschemann-Witzel, J.; de Hooge, I.E.; Almli, V.L. My style, my food, my waste! Consumer food waste-related lifestyle segments. J. Retail. Consum. Serv. 2021, 59, 102353. [CrossRef]

24. Janssens, K.; Lambrechts, W.; van Osch, A.; Semeijn, J. How Consumer Behavior in Daily Food Provisioning Affects Food Waste at Household Level in The Netherlands. Foods 2019, 8, 428. [CrossRef]

25. Coşkun, A.; Özbük, R.M.Y. What influences consumer food waste behavior in restaurants? An application of the extended theory of planned behavior. Waste Manag. 2020, 117, 170-178. [CrossRef]

26. Goh, E.; Jie, F. To waste or not to waste: Exploring motivational factors of Generation Z hospitality employees towards food wastage in the hospitality industry. Int. J. Hosp. Manag. 2019, 80, 126-135. [CrossRef]

27. Sakaguchi, L.; Pak, N.; Potts, M.D. Tackling the issue of food waste in restaurants: Options for measurement method, reduction and behavioral change. J. Clean. Prod. 2018, 180, 430-436. [CrossRef]

28. Beretta, C.; Stoessel, F.; Baier, U.; Hellweg, S. Quantifying food losses and the potential for reduction in Switzerland. Waste Manag. 2013, 33, 764-773. [CrossRef] [PubMed] 
29. Farr-Wharton, G.; Choi, J.H.J.; Foth, M. Food talks back: Exploring the role of mobile applications in reducing domestic food wastage. In Proceedings of the 26th Australian Computer-Human Interaction Conference on Designing Futures: The Future of Design, Sydney, New South Wales, Australia, 2-5 December 2014; pp. 352-361.

30. Stöckli, S.; Dorn, M.; Liechti, S. Normative prompts reduce consumer food waste in restaurants. Waste Manag. 2018, 77, 532-536. [CrossRef] [PubMed]

31. Han, H. Consumer behavior and environmental sustainability in tourism and hospitality: A review of theories, concepts, and latest research. J. Sustain. Tour. 2021, 29, 1021-1042. [CrossRef]

32. Schwartz, S.H. Normative Influences on Altruism. In Advances in Experimental Social Psychology; Elsevier: Amsterdam, The Netherlands, 1977; Volume 10, pp. 221-279.

33. De Groot, J.I.; Steg, L. Morality and prosocial behavior: The role of awareness, responsibility, and norms in the norm activation model. J. Soc. Psychol. 2009, 149, 425-449. [CrossRef]

34. Schwartz, S.H.; Howard, J.A. A normative decision-making model of altruism. In Altruism and Helping Behaviour: Social, Personality and Developmental Perspectives; Erlbaum: Hillsdale, NJ, USA, 1981; pp. 189-211.

35. Shin, Y.H.; Im, J.; Jung, S.E.; Severt, K. The theory of planned behavior and the norm activation model approach to consumer behavior regarding organic menus. Int. J. Hosp. Manag. 2018, 69, 21-29. [CrossRef]

36. Wittenberg, I.; Blöbaum, A.; Matthies, E. Environmental motivations for energy use in PV households: Proposal of a modified norm activation model for the specific context of PV households. J. Environ. Psychol. 2018, 55, 110-120. [CrossRef]

37. Bamberg, S.; Hunecke, M.; Blöbaum, A. Social context, personal norms, and the use of public transportation: Two field studies. J. Environ. Psychol. 2007, 27, 190-203. [CrossRef]

38. Zhang, X.; Liu, J.; Zhao, K. Antecedents of citizens' environmental complaint intention in China: An empirical study based on norm activation model. Resour. Conser. Recycl. 2018, 134, 121-128. [CrossRef]

39. Han, H.; Hyun, S.S. Drivers of customer decision to visit an environmentally responsible museum: Merging the theory of planned behavior and norm activation theory. J. Travel Tour. Mark. 2017, 34, 1155-1168. [CrossRef]

40. Ramus, C.A.; Killmer, A.B.C. Corporate greening through prosocial extra role behaviours: A conceptual framework for employee motivation. Bus. Strategy Environ. 2007, 16, 554-570. [CrossRef]

41. Steg, L.; De Groot, J. Explaining prosocial intentions: Testing causal relationships in the norm activation model. Br. J. Soc. Psychol. 2010, 49, 725-743. [CrossRef] [PubMed]

42. Hutchinson, J.C.; Sherman, T.; Martinovic, N.; Tenenbaum, G. The effect of manipulated self-efficacy on perceived and sustained effort. J. Appl. Sport Psychol. 2008, 20, 457-472. [CrossRef]

43. Han, H.; Chua, B.L.; Hyun, S.S. Eliciting customers' waste reduction and water saving behaviors at a hotel. Int. J. Hosp. Manag. 2020, 87, 102386. [CrossRef]

44. Wang, S.; Wang, J.; Zhao, S.; Yang, S. Information publicity and resident's waste separation behavior: An empirical study based on the norm activation model. Waste Manag. 2019, 87, 33-42. [CrossRef] [PubMed]

45. Van Zomeren, M.; Spears, R.; Leach, C.W. Experimental evidence for a dual pathway model analysis of coping with the climate crisis. J. Environ. Psychol. 2010, 30, 339-346. [CrossRef]

46. Anderson, J.C.; Gerbing, D.W. Structural equation modeling in practice: A review and recommended two-step approach. Psychol. Bull. 1988, 103, 411-423. [CrossRef]

47. Hair, J.F.; Anderson, R.E.; Tatham, R.L.; Black, W.C. Multivariate Data Analysis; Prentice-Hall: Upper Saddle River, NJ, USA, 1998.

48. Fornell, C.; Larcker, D.F. Evaluating structural equation models with unobservable variables and measurement error. J. Mark. Res. 1981, 18, 39-50. [CrossRef]

49. Seoul Metropolitan Government. Pay as You Throw System of Seoul. 2015. Available online: https://seoulsolution.kr/sites/ default/files/policy/2\%EA\%B6\%8C_Environment_Pay\%20as\%20you\%20throw\%20system\%20of\%20Seoul.pdf (accessed on 30 December 2021).

50. Meng, B.; Chua, B.; Ryu, H.; Han, H. Volunteer tourism (VT) traveler behavior: Merging norm activation model and theory of planned behavior. J. Sustain. Tour. 2020, 28, 1947-1969. [CrossRef]

51. Xu, Z.; Zhang, Z.; Liu, H.; Zhong, F.; Bai, J.; Cheng, S. Food-away-from-home plate waste in China: Preference for variety and quantity. Food Policy 2020, 97, 101918. [CrossRef]

52. Filimonau, V.; Todorova, E.; Mzembe, A.; Sauer, L.; Yankholmes, A. A comparative study of food waste management in full service restaurants of the United Kingdom and the Netherlands. J. Clean. Prod. 2020, 258, 120775. [CrossRef]

53. Dolnicar, S.; Juvan, E.; Grün, B. Reducing the plate waste of families at hotel buffets-A quasi-experimental field study. Tour. Manag. 2020, 80, 104103. [CrossRef]

54. Elhoushy, S. Consumers' sustainable food choices: Antecedents and motivational imbalance. Int. J. Hosp. Manag. 2020, 89, 102554. [CrossRef]

55. Ronald, R. The remarkable rise and particular context of younger one-person households in Seoul and Tokyo. City Community 2017, 16, 25-46. [CrossRef]

56. Ajzen, I. The theory of planned behavior. Organ. Behav. Hum. Decis. Process. 1991, 50, 179-211. [CrossRef]

57. Perugini, M.; Bagozzi, R.P. The role of desires and anticipated emotions in goal-directed behaviours: Broadening and deepening the theory of planned behaviour. Br. J. Soc. Psychol. 2001, 40, 79-98. [CrossRef] 
58. Delley, M.; Brunner, T.A. Foodwaste within Swiss households: A segmentation of the population and suggestions for preventive measures. Resour. Conserv. Recycl. 2017, 122, 172-184. [CrossRef]

59. Rodgers, R.F.; Lombardo, C.; Cerolini, S.; Franko, D.L.; Omori, M.; Linardon, J.; Guillaume, S.; Fischer, L.; Fuller-Tyszkiewicz, M. "Waste not and stay at home" evidence of decreased food waste during the COVID-19 pandemic from the US and Italy. Appetite 2021, 160, 105110. [CrossRef]

60. MacInnes, S.; Grün, B.; Dolnicar, S. Habit drives sustainable tourist behaviour. Ann. Tour. Res. 2022, 92, 103329. [CrossRef]

61. Amicarelli, V.; Bux, C. Food waste in Italian households during the COVID-19 pandemic: A self-reporting approach. Food Secur. 2021, 13, 25-37. [CrossRef]

62. Burlea-Schiopoiu, A.; Ogarca, R.F.; Barbu, C.M.; Craciun, L.; Baloi, I.C.; Mihai, L.S. The impact of COVID-19 pandemic on food waste behaviour of young people. J. Clean. Prod. 2021, 294, 126333. [CrossRef] [PubMed]

63. Qian, K.; Javadi, F.; Hiramatsu, M. Influence of the COVID-19 Pandemic on Household Food Waste Behavior in Japan. Sustainability 2020, 12, 9942. [CrossRef]

64. Lee, S.; Han, H.; Radic, A.; Tariq, B. Corporate social responsibility (CSR) as a customer satisfaction and retention strategy in the chain restaurant sector. J. Hosp. Tour. Manag. 2020, 45, 348-358. [CrossRef]

65. Moggi, S.; Bonomi, S.; Ricciardi, F. Against Food Waste: CSR for the Social and Environmental Impact through a Network-Based Organizational Model. Sustainability 2018, 10, 3515. [CrossRef] 